\title{
Anti-nutritional potential of protodioscin and kinetics of degradation in Urochloa grasses ${ }^{1}$
}

\section{Potencial anti-nutricional da protodioscina e cinética de degradação de gramíneas do gênero Urochloa}

\author{
Eduardo Souza Leal²; Luís Carlos Vinhas Ítavo³ ${ }^{3}$ Cacilda Borges do Valle ${ }^{4}$; \\ Camila Celeste Brandão Ferreira Ítavo ${ }^{3}$; Alexandre Menezes Dias; \\ Marcos Barbosa-Ferreira ${ }^{5}$; Claudia Muniz Soares ${ }^{6}$; \\ Gleice Kelli Ayardes de Melo ${ }^{6}$; Valquíria Barbosa Nantes Ferreira ${ }^{7}$
}

\begin{abstract}
This study aimed to evaluate the nutritional value of Urochloa exotic grasses to quantify aspects of antiquality and to identify their correlation with quality grasses. We evaluated the grasses $U$. humidicola $\mathrm{cv}$. Comum, U. humidicola cv. BRS Tupi, U. decumbens cv. Basilisk, D70 U. decumbens and U. ruziziensis ecotype R124, and we grouped them into summer, autumn, winter and spring. We determined the chemical composition, in vitro digestibility, levels of protodioscin and cumulative gas production from the leaves of grass materials in nature. Basilisk and D70 showed higher content protodioscin in all seasons, with the highest values (31.4 and $27.4 \mathrm{~g} \mathrm{~kg}^{-1}$, respectively) in spring. D70 had a crude protein content of $140.0 \mathrm{~g} \mathrm{~kg}^{-1}$ in summer and a better in vitro digestibility of dry matter $\left(888.7 \mathrm{~g} \mathrm{~kg}^{-1}\right)$. R124 had a higher cumulative gas production in the spring $\left(16.44 \mathrm{~mL}\right.$ gas $\left.100 \mathrm{mg} \mathrm{DM}^{-1}\right)$. U. humidicola (Comum and BRS Tupi) presented lower protodioscin concentrations (1.22 and $1.07 \mathrm{~g} \mathrm{~kg} \mathrm{DM}^{-1}$, respectively), and $U$. decumbens (Basilisk and D70) presented higher concentrations (27.25 and $24.55 \mathrm{~g} \mathrm{~kg} \mathrm{DM}^{-1}$, respectively). The presence of protodioscin interfered with in vitro digestibility results and cumulative gas production in vitro.
\end{abstract}

Key words: Fodder. Gas production. In vitro digestibility.

\section{Resumo}

Objetivou-se avaliar o valor nutricional e quantificar os aspectos de anti-qualidade e suas correlações com a qualidade de gramíneas exóticas do gênero Urochloa. Foram avaliadas as gramíneas Urochloa. humidicola cv. Comum, Urochloa humidicola cv. BRS Tupi, Urochloa decumbens cv. Basilisk, Urochloa decumbens ecotipo D70 e Urochloa ruziziensis ecotipo R124 e agrupadas em épocas verão,

1 Projeto financiado pelo CNPq, (processo n 563988/2010-0) e pela FUNDECT (processo 23/200.145/2011).

2 Discente do Curso de Doutorado, Programa de Pós-Graduação em Ciências Ambientais e Sustentabilidade Agropecuária, Universidade Católica Dom Bosco, UCDB, Campo Grande, MS, Brasil. Bolsista Capes. E-mail: eduardoleal.zoo@gmail.com

3 Profs., Faculdade de Medicina Veterinária e Zootecnia, Universidade Federal de Mato Grosso do Sul, FAMEZ/UFMS, Campo Grande, MS, Brasil. E-mail: luis.itavo@ufms.br; camila.itavo@ufms.br; alexandre.menezes@ufms.br

4 Pesquisadora, EMBRAPA Gado de Corte, Campo Grande, MS, Brasil. E-mail: cacilda@cnpgc.embrapa.br

5 Prof., Programa de Pós-Graduação em Produção e Gestão Agroindustrial e Coordenador CTO, Centro Tecnológico de Ovinos, Universidade Anhanguera, UNIDERP, Campo Grande, MS, Brasil. E-mail: profmarcosvet@gmail.com

6 Discentes do Curso de Doutorado do Programa de Pós-Graduação em Ciência Animal, UFMS, Campo Grande, MS, Brasil. Bolsistas da Capes. E-mail: claudiabiotec@gmail.com; gleiceayardes@gmail.com

7 Pesquisadora, Instituto de Química, Universidade Federal de Mato Grosso do Sul, INQUI/UFMS, Campo Grande, MS, Brasil. E-mail: valbnf@hotmail.com

Author for correspondence 
outono, inverno e primavera. Foram determinados composição bromatológica, digestibilidade in vitro, teores de protodioscina e produção cumulativa de gáses das folhas das gramíneas material in natura. Basilisk e D70 apresentaram os maiores teores de protodioscina em todas as épocas do ano, com maior valor observado na primavera, 31,4 e 27,4 $\mathrm{g} \mathrm{kg}^{-1}$, respectivamente. D70 apresentou maior teor de proteína bruta $\left(140,0 \mathrm{~g} \mathrm{~kg}^{-1}\right)$ no verão e maior digestibilidade in vitro da matéria seca $\left(888,7 \mathrm{~g} \mathrm{~kg}^{-}\right.$ $\left.{ }^{1}\right)$. R124 teve maior produção cumulativa de gás na primavera $\left(16,44 \mathrm{~mL}\right.$ de gás $100 \mathrm{mg}$ de $\left.\mathrm{MS}^{-1}\right)$. $U$. humidicola (Comum e BRS Tupi) apresentaram os menores teores de protodioscina (1,22 e 1,07 $\mathrm{g} \mathrm{kg}^{-1}$ MS, respectivamente). Houve correlação negativa entre o teor de protodioscina e a FDN, a fração C (Lag time) e a produção cumulativa de gás in vitro. A presença de protodioscina interfere nos resultados de digestibilidade in vitro e a produção cumulativa de gases in vitro.

Palavras-chave: Digestibilidade in vitro. Forragem. Produção de gás.

\section{Introduction}

Grasses of the Urochloa genus comprise approximately $85 \%$ of pastures in Brazil. Urochloa brizantha cv. Marandu, U. decumbens cv. Basilisk and $U$. humidicola cv. Tully grow in the Cerrado region (MOREIRA et al., 2009). Grasses of the Urochloa genus have been reported as the main causes of hepatogenous poisoning in ruminants. The disease is attributed to steroid lithogenic saponins in these grasses (BRUM et al, 2009; RIET-CORREA et al., 2011). One of the major clinical signs of intoxication photosensitivity is lesions on the skin after exposure to sunlight due to the accumulation of subcutaneous tissue filoeritrina (SANTOS et al., 2008).

Saponins are derived from diosgenin sapogenins (25R), yamogenina (25S) (CRUZ et al., 2000) and protodioscin, which, after passing through the metabolism in the gastrointestinal tract of animals, result in epismilagenin sapogenins and episarsasapogenin, respectively, which are responsible for the formation of bile crystals. The formation of these crystals causes inflammation in and an obstruction of the biliary system, resulting in hepatitis, jaundice and photosensitization (SANTOS et al., 2008).

$U$. decumbens intoxication can occur at any time of year, and it is considered to have high concentration of saponins year round. Other studies have shown that the content of steroidal saponins in Urochloa spp., and hence toxicity, is higher in the seeds' falling phase than in other phases (MENDONÇA et al., 2008).
It is necessary to relate the physicochemical factors of Urochloa grasses to protodioscin concentrations in order to identify their possible interactions and to better understand these secondary metabolites and their importance for pasture quality. This study aimed to evaluate the anti-nutritional potential of the protodioscin present in Urochloa humidicola cv. Comum, Urochloa humidicola cv. BRS Tupi, Urochloa decumbens cv. Basilisk, Urochloa decumbens ecotype D70 and Urochloa ruziziensis ecotype R124 by assessing the in vitro digestibility and kinetics of degradation in the rumen liquor grouped into seasons: summer, autumn, winter and spring.

\section{Materials and Methods}

The experiment was conducted at the Laboratory of Biotechnology and Animal Nutrition at Dom Bosco Catholic University (UCDB) and the Natural Products Chemistry Laboratory, Department of Chemistry of the Federal University of Mato Grosso do Sul (UFMS) located in the municipality of Campo Grande, MS.

Samples of green leaves of Urochloa grasses were harvested from experimental plots belonging to the Brazilian Agricultural Research Corporation (EMBRAPA), Campo Grande, MS. Harvesting occurred in the morning every 30 days in 20 flowerbeds, with four replications per flowerbed, which measured $3 \mathrm{~m} \times 3 \mathrm{~m}$ and contained $U$. decumbens, $U$. ruziziensis and $U$. humidicola or the following cultivars: $U$. decumbens cv. Basilisk and 
ecotype BRA001996 (D70); U. ruziziensis ecotype R124; U. humidicola cv. Comum and BRS Tupi. The average results of samples taken every 30 days were grouped by season-i.e., summer (January to March), autumn (April and May), winter (June to August) and spring (September and October) -for interpretation, comparison and presentation results.

Freely growing green-leaf samples were collected monthly in the form of grazing, according to the methodology proposed by Moraes et al. (2005). There was a total of four samplings, and at the end, a composite sample of grass was created.

Samples were treated in the laboratory. They were pre-dried with a forced-ventilation oven at $55^{\circ} \mathrm{C}$ for 72 hours and pounded into mill with a sieve endowed with 1-mm screens. The chemical composition was determined based on the ash content, organic matter (OM), and crude protein (CP) content according to the methodology described by Silva and Queiroz (2002) and the neutral detergent fiber (NDF) and acid detergent fiber (ADF) according to the methods described by Van Soest (1965).

The buffer solution was prepared in the same way for the two in vitro procedures (digestibilityIVD and cumulative gas production)-Solution A (g L ${ }^{-1}$ ): $10.0 \mathrm{~g} \mathrm{KH}_{2} \mathrm{PO}_{4} ; 0.5 \mathrm{~g} \mathrm{MgSO}_{4}-7 \mathrm{H} 2 \mathrm{O} ; 0.5 \mathrm{~g}$ $\mathrm{NaCl} ; 0.1 \mathrm{~g} \mathrm{CaCl}_{2} 2 \mathrm{H}_{2} \mathrm{O}$; $0.5 \mathrm{~g}$ urea; Solution B (100 $\mathrm{ml} \mathrm{g}^{-1}$ ): $15.0 \mathrm{~g} \mathrm{Na}_{2} \mathrm{CO} ; 1.0 \mathrm{~g} \mathrm{Na}_{2} \mathrm{~S}-9 \mathrm{H}_{2} \mathrm{O}$. Solutions $\mathrm{A}$ and $\mathrm{B}$ were mixed in a $1: 5$ ratio. The $\mathrm{pH}$ and temperature were 6.8 and $39^{\circ} \mathrm{C}$, respectively.

To measure in vitro digestibility (IVD), the technique described by Tilley and Terry (1963) was adapted to the artificial rumen developed by ANKOM ${ }^{\circledR}$, as described by Holden (1999), using the methodology of the rumen fermenter (incubator anaerobic, MA443, Marconi). Samples were weighed in triplicate, with approximately $0.32 \mathrm{~g}$ of sample in TNT filter bags with dimensions of 4.0 $\mathrm{x} 4.0 \mathrm{~cm}$ and a density of $100 \mathrm{~g} / \mathrm{m}^{2}$. Samples were placed in glass jars and kept in an incubator with a controlled temperature $\left(39^{\circ} \mathrm{C}\right)$ after the addition of the buffer solution ( $\mathrm{pH}$ 6.8) and inoculum from the three different rumen fistulated cows kept in a Urochloa brizantha pasture. After 72 hours of incubation, the bags were washed in running water to provide a clear appearance with a $\mathrm{pH}$ of 7 for drying, and then, they were weighed with waste. After correction by a blank bag, the in vitro digestibility of DM, OM, NDF and ADF was calculated based on the difference between the quantity of nutrients incubated and the nutrients in residue, according to the methodology described by Silva and Queiroz (2002).

IVD $=\mathrm{g}$ incubated substrate $-(\mathrm{g}$ residual substrate - white g) / g substrate incubated x 100 .

The determination of protodioscin content was performed by high-performance liquid chromatography (HPLC), employing an evaporative light scattering detector (ELSD), Shimadzu, according to the technique of Ganzera et al. (2001).

For in vitro gas production, $0.5 \mathrm{~g}$ of sample was weighed in triplicate, incubated with buffer solution ( $\mathrm{pH}$ 6.8) and inoculum from the three different rumen fistulated cows kept in the Urochloa brizantha pasture. The kinetics of the fermentation of the food was evaluated for 72 hours through a gas-production process using a wireless computer system with a pressure transducer and communication by radio frequency ( $\mathrm{RF} A \mathrm{ANKOM}{ }^{\circledR}$ - Gas production system).

The pressure data (psi) were collected every 5 min and processed for the cumulative gas produced ( $\mathrm{ml}$ of gas $100 \mathrm{mg}$ DM-1 incubated). The parameters of gas production kinetics were obtained using twocompartment logistic model proposed by Pell and Schofield (1993): $\mathrm{y}=\mathrm{A} /\{1+\exp [2+4 * \mathrm{~B} *(\mathrm{C}-\mathrm{t})]\}+\mathrm{D}$ $/\left\{1+\exp \left[4+2 * E^{*}(C-t)\right]\right\}$, where $y=$ total gas volume at time $\mathrm{t}$ (extent of degradation); $\mathrm{A}$ and $\mathrm{D}=$ volume of gas (ml) of rapid degradation (soluble sugars and starch) and slow degradation (cellulose and hemicellulose), respectively; $\mathrm{B}$ and $\mathrm{E}=$ degradation rate of fractions of fast and slow digestion $\left(\mathrm{g} \mathrm{kg}^{-1} . \mathrm{h}\right)$, respectively; and $\mathrm{C}=$ lag time $(\mathrm{h})$. 
The data of the chemical composition and in vitro digestibility were evaluated through an analysis of variance (ANOVA) in a completely randomized design with a $5 \times 4$ factorial scheme (five cultivars in four seasons). The Gauss-Newton procedure was used in cumulative production gas to estimate the fermentation parameters. The System for Statistical and Genetic Analysis (UFV, 1997) was used, and the means were compared by Tukey test using a significance level of $\mathrm{P}<0.05$.

\section{Results and Discussion}

There was a significant difference in the protodioscin content for all grasses across seasons. $U$. humidicola cv. Comum in the summer showed the lowest value $\left(1.0 \mathrm{~g} \mathrm{~kg}^{-1}\right)$ and reached $\left(1.4 \mathrm{~g} \mathrm{~kg}^{-}\right.$ ${ }^{1}$ ) in spring (Table 1). U. decumbens cv Basilisk and the D70 ecotype had the largest protodioscin content. The R124 ecotype (U. ruziziensis) showed an intermediate protodioscin content that varied from 4.7 to $13.0 \mathrm{~g} \mathrm{~kg}^{-1}$, according to the time of year (Table 1).

Table 1. Protodioscin concentration and chemical composition of the leaves of Urochloa grasses.

\begin{tabular}{|c|c|c|c|c|c|c|}
\hline \multirow{2}{*}{ Epoch } & \multicolumn{2}{|c|}{ U. humidicola } & \multicolumn{2}{|c|}{ U. decumbens } & \multirow{2}{*}{$\begin{array}{c}\text { U. ruziziensis } \\
\text { R124 } \\
\end{array}$} & \multirow{2}{*}{$\mathrm{P}$} \\
\hline & Comum & Tupi & Basilisk & D70 & & \\
\hline \multicolumn{7}{|c|}{ Protodioscin $\left(\mathrm{g} \mathrm{kg} \mathrm{DM}^{-1}\right)$} \\
\hline Summer & $1.0^{\mathrm{bC}}$ & $0.9^{\mathrm{bc}}$ & $21.5^{\mathrm{cA}}$ & $18.4^{\mathrm{bA}}$ & $8.1^{\mathrm{bB}}$ & 0.001 \\
\hline Autumn & $1.2^{\mathrm{ab} \mathrm{C}}$ & $1.0^{\mathrm{bC}}$ & $29.0^{\mathrm{ab} \mathrm{A}}$ & $24.9^{\mathrm{aA}}$ & $13.0^{\mathrm{a} B}$ & 0.001 \\
\hline Winter & $1.3^{\mathrm{a} \mathrm{C}}$ & $1.3^{\mathrm{aC}}$ & $27.1^{\mathrm{bA}}$ & $27.5^{\mathrm{aA}}$ & $8.4^{\mathrm{b} \mathrm{B}}$ & 0.001 \\
\hline Spring & $1.4^{\mathrm{a} \mathrm{D}}$ & $1.1^{\mathrm{abD}}$ & $31.4^{\mathrm{aA}}$ & $27.4^{\mathrm{a} B}$ & $4.7^{\mathrm{cC}}$ & 0.001 \\
\hline $\mathrm{P}$ & 0.003 & 0.006 & 0.002 & 0.002 & 0.001 & \\
\hline \multicolumn{7}{|c|}{ Organic matter $\left(\mathrm{g} \mathrm{kg} \mathrm{DM}^{-1}\right)$} \\
\hline Summer & $930.6^{\mathrm{a} B}$ & $940.0^{\mathrm{a} \mathrm{A}}$ & $921.9^{\mathrm{b} \text { BC }}$ & $917.4^{\mathrm{aC}}$ & $920.3^{\mathrm{a} B C}$ & 0.001 \\
\hline Autumn & $927.0^{\mathrm{ab} \mathrm{A}}$ & $932.3^{\mathrm{bA}}$ & $930.1^{\mathrm{aA}}$ & $917.5^{\mathrm{a} \mathrm{B}}$ & $916.0^{\mathrm{a} B}$ & 0.001 \\
\hline Winter & $920.9^{\mathrm{c} \mathrm{AB}}$ & $924.5^{\mathrm{cA}}$ & $915.5^{\mathrm{cB}}$ & $923.0^{\mathrm{aA}}$ & $916.7^{\mathrm{a} \mathrm{B}}$ & 0.001 \\
\hline Spring & $924.8^{\mathrm{bA}}$ & $924.0^{\mathrm{cA}}$ & $915.1^{\mathrm{bc} \mathrm{B}}$ & $915.8^{\mathrm{a} \mathrm{B}}$ & $911.0^{\mathrm{aB}}$ & 0.001 \\
\hline $\mathrm{P}$ & 0.001 & 0.001 & 0.001 & 0.240 & 0.400 & \\
\hline \multicolumn{7}{|c|}{ Crude protein $\left(\mathrm{g} \mathrm{kg} \mathrm{DM}^{-1}\right)$} \\
\hline Summer & $98.9^{\mathrm{c} B C}$ & $87.9^{\mathrm{bc}}$ & $107.0^{\mathrm{a} B}$ & $140.2^{\mathrm{aA}}$ & $104.5^{\mathrm{ab} B}$ & 0.001 \\
\hline Autumn & $111.6^{\mathrm{bAB}}$ & $83.1^{\mathrm{bC}}$ & $102.6^{\mathrm{a} \mathrm{B}}$ & $119.8^{\mathrm{aA}}$ & $102.8^{\mathrm{ab} B}$ & 0.001 \\
\hline Winter & $131.5^{\mathrm{aA}}$ & $87.1^{\mathrm{bC}}$ & $108.2^{\mathrm{a} \mathrm{B}}$ & $127.1^{\mathrm{aA}}$ & $101.8^{\mathrm{bBC}}$ & 0.001 \\
\hline Spring & $122.9^{\mathrm{ab} \mathrm{AB}}$ & $101.6^{\mathrm{a} B}$ & $117.9^{\mathrm{aAB}}$ & $125.4^{\mathrm{aA}}$ & $121.7^{\mathrm{aAB}}$ & 0.001 \\
\hline $\mathrm{P}$ & 0.001 & 0.007 & 0.142 & 0.128 & 0.050 & \\
\hline \multicolumn{7}{|c|}{ Neutral detergent fiber $\left(\mathrm{g} \mathrm{kg} \mathrm{DM}^{-1}\right)$} \\
\hline Summer & $658.4^{\mathrm{a} \mathrm{B}}$ & $684.4^{\mathrm{a} \mathrm{B}}$ & $719.0^{\mathrm{aA}}$ & $536.0^{\mathrm{aC}}$ & $665.1^{\mathrm{a} \mathrm{B}}$ & 0.001 \\
\hline Autumn & $615.4^{\mathrm{ab} B}$ & $697.3^{\mathrm{aA}}$ & $693.5^{\mathrm{aA}}$ & $506.8^{\mathrm{aC}}$ & $639.5^{\mathrm{aAB}}$ & 0.001 \\
\hline Winter & $620.9^{\mathrm{ab} C}$ & $677.0^{\mathrm{aA}}$ & $694.8^{\mathrm{aA}}$ & $524.3^{\mathrm{aD}}$ & $637.8^{\mathrm{a} \mathrm{B}}$ & 0.001 \\
\hline Spring & $607.2^{\mathrm{bC}}$ & $658.0^{\mathrm{a} B}$ & $692.3^{\mathrm{aA}}$ & $522.2^{\mathrm{aD}}$ & $608.7^{\mathrm{a} \mathrm{C}}$ & 0.001 \\
\hline $\mathrm{P}$ & 0.031 & 0.156 & 0.400 & 0.400 & 0.354 & \\
\hline \multicolumn{7}{|c|}{ Acid detergent fiber $\left(\mathrm{g} \mathrm{kg} \mathrm{DM}^{-1}\right)$} \\
\hline Summer & $377.8^{\mathrm{aA}}$ & $384.5^{\mathrm{ab} \mathrm{A}}$ & $349.8^{\mathrm{ab} \mathrm{AB}}$ & $299.5^{\text {a B }}$ & $346.1^{\mathrm{AB}}$ & 0.001 \\
\hline Autumn & $344.1^{\mathrm{ab} \mathrm{B}}$ & $409.2^{\mathrm{aA}}$ & $331.6^{\mathrm{ac}}$ & $280.6^{\mathrm{aD}}$ & $345.2^{\mathrm{B}}$ & 0.001 \\
\hline Winter & $339.9^{\mathrm{ab} \mathrm{BC}}$ & $395.7^{\mathrm{ab} \mathrm{A}}$ & $329.5^{\mathrm{aC}}$ & $282.6^{\mathrm{aD}}$ & $346.3^{\mathrm{B}}$ & 0.001 \\
\hline Spring & $330.5^{\mathrm{b} \mathrm{B}}$ & $365.9^{\mathrm{bA}}$ & $316.6^{\mathrm{ac}}$ & $284.0^{\mathrm{a} D}$ & $317.7^{\mathrm{C}}$ & 0.001 \\
\hline $\mathrm{P}$ & 0.055 & 0.040 & 0.183 & 0.400 & 0.400 & \\
\hline
\end{tabular}

* Means followed by distinct letters, lowercase in the column and uppercase on the line, differ by Tukey test $(\mathrm{P}<0.05)$. 
$U$. decumbens had the highest protodioscin content, i.e., $27.3 \mathrm{~g} \mathrm{~kg}^{-1}$ for $\mathrm{cv}$. Basilisk and 24.6 $\mathrm{g} \mathrm{kg}^{-1}$ for the D70 ecotype. In spring, the greatest protodioscin concentration $\left(31.4 \mathrm{~g} \mathrm{~kg}^{-1}\right)$ was observed for cv. Basilisk. U. humidicola cv Comum and cv. Tupi showed the lowest protodioscin content (1.2 $\mathrm{g} \mathrm{kg}^{-1}$ and $1.1 \mathrm{~g} \mathrm{~kg}^{-1}$, respectively).

The protodioscin concentrations varied from $0.9 \mathrm{~g} \mathrm{~kg}^{-1}$ to $31.4 \mathrm{~g} \mathrm{~kg}^{-1}$. The results showed that the protodioscin content varied across and within species at different times of the year. This finding shows that saponin concentration is dependent on the physiological state, development and maturity of the grass. Regardless of the season and the plant development, intoxication cases were described. Brum et al. (2009) found the protodioscin contents for $U$. brizantha and $U$. decumbens at different stages of development to be $5.30 \mathrm{~g} \mathrm{~kg}^{-1}$ and $20.9 \mathrm{~g}$ $\mathrm{kg}^{-1}$, respectively.

Lemos et al. (1998) reported two intoxication cases in caprines kept in Urochloa decumbens in the state of Mato Grosso do Sul in the dry season. Similar results were published by Mendonça et al. (2008), who reported cases of photosensitivity in adult sheep raised in Urochloa decumbens pastures in Mato Grosso state at the end of the dry season.

Although reports in the literature have associated hepatogenous photosensitivity to $U$. humidicola (BARBOSA et al., 2006) and U. ruziziensis (RIET-CORREA et al., 2011), several studies have noted that $U$. decumbens (DRIEMEIER et al., 1998; LEMOS et al., 1998;. BRUM et al., 2007; MENDONÇA et al., 2008; SATURNINO et al., 2010; PORTO et al., 2013) is primarily responsible for poisoning. Brum et al. (2007) reported a case of six lambs and a sheep that displayed clinical signs of photosensitivity when grazing $U$. decumbens $\mathrm{cv}$ Basilisk with a protodioscin content of $23.6 \mathrm{~g} \mathrm{~kg}^{-1}$. In this same experiment, cattle grazing grass with the same protodioscin concentration (16.3 $\mathrm{g} \mathrm{kg}^{-}$ $\left.{ }^{1}\right)$ did not display signs of intoxication. However, protodioscin concentrations of $9.4 \mathrm{~g} \mathrm{~kg}^{-1}$ were found in Urochloa decumbens pastures, and lambs approximately four months old presented clinical signs of photosensitivity (PORTO et al., 2013).

These findings suggest that intoxication may be related to the concentration of saponins in grass. However, it is known that saponin concentrations evaluated only in the laboratory do not correlate with cases of poisoned fields; they may be subject to different variables, such as the time of year, endurance, individual sensitivity, the type and category of animals grazing, the age of the plant material, the period and the storage conditions (RIET-CORREA et al., 2011).

There was a significant difference $(\mathrm{P}<0.05)$ in organic matter $(\mathrm{OM})$ across seasons for $U$. humidicola cv. Comum cv. Tupi and U. decumbens cv. Basilisk; OM was greater in the summer for cv. Comum cv. Tupi, with values of 930.6 and 940.0 $\mathrm{g} \mathrm{kg}^{-1}$, respectively. The cv. Basilisk showed the highest concentration of OM in autumn $\left(930.1 \mathrm{~g} \mathrm{~kg}^{-}\right.$ 1; Table 1).

In terms of the content of crude protein (CP), there was no significant difference across seasons between the cv. Comum, cv. Tupi and the R124 ecotype. We observed that cv. Tupi showed less variation across seasons, whereas cv. Comum showed the highest variation (98.9 to $131.5 \mathrm{~g} \mathrm{~kg}^{-}$ 1; Table 1). There were significant differences in the CP content between the grasses. Ecotype D70 showed the highest CP content in all seasons (Table $1)$.

It was observed that increased fiber resulted in minor CP values and DM digestibility. Smaller values of CP and IVDMD and higher fiber were observed in summer, and the negative correlation among those variables (Tables 2, 3 and 4) directly influenced the quality of the grasses.

Fluctuations in protein content occur primarily with the advancement of grass maturity. Plants with a low protein content generally exhibit the low growth, chlorosis and senescence of older leaves (FIORENTIN et al., 2012). NDF content is inversely 
related to the consumption and the foraging of energy content, and it presents low degradation and a slow passage rate in the reticulum-rumen. In this way, diets with large contents of NDF reduce the total dry matter intake, according to limitations caused by the rumen fill (KOZLOSKI et al., 2006).

The CP content in the grasses presented variation from 83.1 to $142.7 \mathrm{~g} \mathrm{~kg}-1$, remaining above the lower limit of $70 \mathrm{~g} \mathrm{~kg}-1$, proposed by Van Soest (1994) as being necessary to maintain the nutritional requirements of rumen microorganisms. However, this value is considered not to limit the activity of rumen microorganisms, and this activity is suitable only to keep animals, which may compromise the digestibility of highly fibrous forage (CARVALHO et al., 2015).

There was a significant difference across seasons for NDF, ADF, IVDDM, IVDOM and IVDNDF. cv. Comum presented the highest NDF content in summer and the lowest in spring (658.4 and 607.2 $\mathrm{g} \mathrm{kg}^{-1}$, respectively). The variation in the average NDF contents was 709.9 to $808.1 \mathrm{~g} \mathrm{~kg}^{-1}$, values that according to Fox et al. (2004) and Cannas et al. (2004) are high. According to these authors, the minimum required in the diet would be 200 to $245 \mathrm{~g} \mathrm{~kg}^{-1} \mathrm{NDF}$ for fermentation and microbial protein synthesis to occur. Diets rich in fiber act as regulators of consumption, occasioning the physical filler, and the limited availability of ingestion results in a deficiency of energy consumption.

Among the grasses studied, cv. Basilisk had the highest NDF content, and no significant difference across seasons (average $700 \mathrm{~g} \mathrm{~kg}^{-1}$ ) was detected. In the summer, cv. Comum and cv. Tupi had the highest ADF contents, 377.8 and $384.5 \mathrm{~g} \mathrm{~kg}-1$, respectively. The cv. Tupi, in autumn had the highest ADF content (409.2 $\mathrm{g} \mathrm{kg}^{-1}$ ). There was no significant difference in ADF across seasons for other grasses (Table 1).

There was a significant difference across seasons for the ADF content. In the summer, cv. Comum and cv. Tupi showed the highest values, 377.8 and $384.5 \mathrm{~g} \mathrm{~kg}^{-1}$, respectively. In the autumn, cv. Tupi had the highest ADF content (409.2 $\left.\mathrm{g} \mathrm{kg}^{-1}\right)$. The
ADF varies as a function of an increased proportion of structurally lignified tissue and the grassy developmental stage, which reduces forage quality tendered due to the accelerated lignification process of these tissues (BERCHIELLI et al., 2001).

In summer, cv. Comum and cv. Basilisk showed an IVDDM of 698.5 and $722.9 \mathrm{~g} \mathrm{~kg}^{-1}$, respectively (Table 2). This outcome sustains the negative correlation of NDF (-0.64 and -0.46) with IVDDM and IVDOM and the positive correlation of NDF with the CP content (0.73 and 0.63; Table 4). Ecotype D70 presented IVDDM (834.0 $\left.\mathrm{g} \mathrm{kg}^{-1}\right)$ higher than that of the other grasses, due to its low proportion of NDF and ADF and its high protein contents. There was no significant difference across seasons in the IVDMD contents for the cv. Tupi, the R124 ecotype and the D70 ecotype (Table 2). There were significant differences across grasses in the same season for IVDDM in all periods; the D70 ecotype showed the highest level in every season, whereas the cv. Tupi presented the lowest IVDDM (Table 2).

The IVDDM results show a significant difference in the grasses across seasons. Silva et al. (2004) evaluated the nutritional value of Urochloa humidicola, finding that it obtained the largest DM digestibility value $\left(620.2 \mathrm{~g} \mathrm{~kg}^{-1}\right)$. They demonstrated that cv. Comum showed a better IVDDM, whereas cv. Tupi had the lowest IVDDM (624.2 to 650.4 g kg-1). Moraes et al. (2005) evaluated Urochloa decumbens (syn. Brachiaria decumbens) harvested under manual grazing simulation and found an IVDMD average of $570.7 \mathrm{~g} \mathrm{~kg}^{-1}$.

The gas-production technique in vitro showed that the anti-nutritional factor (protodioscin) interferes in the dynamics of degradation. However, when observed only by the in vitro digestibility technique, this negative effect of the anti-nutritional factor is not noticed; this occurs possibly because in the method of in vitro digestibility, those factors are diluted in rumen after being released in nylon bags and do not appreciably affect ruminal fermentation (EL-WAZIRY et al., 2007). 
Table 2. Digestibility of the leaves of Urochloa grasses.

\begin{tabular}{|c|c|c|c|c|c|c|}
\hline \multirow{2}{*}{ Epoch } & \multicolumn{2}{|c|}{ U. humidicola } & \multicolumn{2}{|c|}{ U. decumbens } & \multirow{2}{*}{$\frac{\text { U. ruziziensis }}{\mathrm{R} 124}$} & \multirow{2}{*}{$\mathrm{P}$} \\
\hline & Comum & Tupi & Basilisk & $\mathrm{D} 70$ & & \\
\hline \multicolumn{7}{|c|}{ In vitro digestibility of Dry Matter $\left(\mathrm{g} \mathrm{kg}^{-1}\right)$} \\
\hline Summer & $698.5^{\mathrm{b} B C}$ & $650.4^{\mathrm{C}}$ & $722.9^{\mathrm{b} B}$ & $888.7^{\mathrm{A}}$ & $688.0^{\mathrm{BC}}$ & 0.001 \\
\hline Autumn & $769.9^{\mathrm{a} \mathrm{B}}$ & $647.3^{\mathrm{C}}$ & $767.5^{\mathrm{ab} \mathrm{B}}$ & $857.1^{\mathrm{A}}$ & $733.1^{\mathrm{B}}$ & 0.001 \\
\hline Winter & $774.5^{\mathrm{a} \mathrm{B}}$ & $624.2^{\mathrm{D}}$ & $746.1^{\text {ab B }}$ & $833.7^{\mathrm{A}}$ & $684.0^{\mathrm{C}}$ & 0.001 \\
\hline Spring & $806.2^{\mathrm{a} A \mathrm{~B}}$ & $644.3^{\mathrm{D}}$ & $791.7^{\mathrm{a} \mathrm{B}}$ & $836.6^{\mathrm{A}}$ & $687.5^{\mathrm{C}}$ & 0.001 \\
\hline $\mathrm{P}$ & 0.002 & 0.400 & 0.048 & 0.246 & 0.306 & \\
\hline \multicolumn{7}{|c|}{ In vitro digestibility of organic matter $\left(\mathrm{g} \mathrm{kg}^{-1}\right)$} \\
\hline Summer & $745.5^{\text {b B }}$ & $683.7^{\mathrm{ab} \mathrm{AI}}$ & $694.1^{\mathrm{cAB}}$ & $751.6^{\mathrm{A}}$ & $696.8^{\mathrm{AB}}$ & 0.001 \\
\hline Autumn & $804.8^{\mathrm{aA}}$ & $653.8^{\mathrm{bC}}$ & $801.3^{\mathrm{aA}}$ & $793.0^{\mathrm{A}}$ & $739.4^{\mathrm{B}}$ & 0.001 \\
\hline Winter & $792.9^{\mathrm{aA}}$ & $678.1^{\mathrm{bC}}$ & $736.2^{\text {bc B }}$ & $776.5^{\mathrm{A}}$ & $732.2^{\mathrm{B}}$ & 0.001 \\
\hline Spring & $815.2^{\mathrm{aA}}$ & $729.0^{\mathrm{a} B}$ & $776.4^{\mathrm{ab} \mathrm{AB}}$ & $753.0^{\mathrm{AB}}$ & $772.7^{\mathrm{AB}}$ & 0.001 \\
\hline $\mathrm{P}$ & 0.011 & 0.014 & 0.001 & 0.388 & 0.081 & \\
\hline \multicolumn{7}{|c|}{ In vitro digestibility fiber in neutral detergent $\left(\mathrm{g} \mathrm{kg}^{-1}\right)$} \\
\hline Summer & $594.1^{\mathrm{bB}}$ & $548.9^{\mathrm{C}}$ & $665.8^{\mathrm{bA}}$ & $679.2^{\mathrm{A}}$ & $615.6^{\mathrm{B}}$ & 0.001 \\
\hline Autumn & $680.0^{\mathrm{a} B}$ & $568.1^{\mathrm{C}}$ & $708.0^{\mathrm{ab} B}$ & $740.4^{\mathrm{A}}$ & $690.0^{\mathrm{B}}$ & 0.001 \\
\hline Winter & $694.1^{\text {a B }}$ & $522.6^{\mathrm{D}}$ & $686.0^{\mathrm{ab} B}$ & $711.7^{\mathrm{A}}$ & $599.7^{\mathrm{C}}$ & 0.001 \\
\hline Spring & $735.1^{\mathrm{aA}}$ & $545.0^{\mathrm{D}}$ & $740.9^{\mathrm{aA}}$ & $713.3^{\mathrm{B}}$ & $647.2^{\mathrm{C}}$ & 0.001 \\
\hline $\mathrm{P}$ & 0.001 & 0.400 & 0.030 & 0.280 & 0.199 & \\
\hline \multicolumn{7}{|c|}{ In vitro digestibility fiber in acid detergent $\left(\mathrm{g} \mathrm{kg}^{-1}\right)$} \\
\hline Summer & $526.4^{\mathrm{bC}}$ & $537.0^{\mathrm{BC}}$ & $580.6^{\mathrm{b} B}$ & $651.6^{\mathrm{A}}$ & $509.0^{\mathrm{ab} C}$ & 0.001 \\
\hline Autumn & $625.8^{\mathrm{a} \mathrm{C}}$ & $531.7^{\mathrm{D}}$ & $648.6^{\mathrm{a} B}$ & $712.1^{\mathrm{A}}$ & $572.8^{\mathrm{a} C D}$ & 0.001 \\
\hline Winter & $625.2^{\mathrm{aAB}}$ & $487.4^{\mathrm{C}}$ & $610.9^{\mathrm{ab} B}$ & $681.2^{\mathrm{A}}$ & $447.7^{\mathrm{b} \mathrm{C}}$ & 0.001 \\
\hline Spring & $678.1^{\mathrm{aA}}$ & $515.6^{\mathrm{B}}$ & $666.7^{\mathrm{aA}}$ & $685.0^{\mathrm{A}}$ & $473.1^{\mathrm{ab} C}$ & 0.001 \\
\hline $\mathrm{P}$ & 0.001 & 0.400 & 0.001 & 0.293 & 0.059 & \\
\hline
\end{tabular}

* Means followed by distinct letters, lowercase in the column and uppercase on the line, differ by Tukey test $(\mathrm{P}<0.05)$.

There was a significant effect of season on IVDDM in grasses cv. Comum, cv. Tupi, ecotype R124 and cv. Basilisk. The lowest value was observed for cv. Tupi (653.8 $\mathrm{g} \mathrm{kg}^{-1}$ in autumn). However, cv. Basilisk showed greater variation across seasons: $801.3 \mathrm{~g} \mathrm{~kg}^{-1}$ in autumn and 694.1 $\mathrm{g} \mathrm{kg}^{-1}$ in summer (Table 2). When comparing the IVDOM averages of the grasses, we observed a significant difference in every season, and cv. Comum showed the highest IVDOM in the autumn, winter and spring, with 804.8, 792.9 and $815.2 \mathrm{~g} \mathrm{~kg}^{-}$ ${ }^{1}$, respectively. (Table 2 ).

There was a significant difference across seasons in IVDNDF for cv. Comum and cv. Basilisk. In summer, cv. Comum presented a lower IVDNDF (594.1 $\mathrm{g} \mathrm{kg}^{-1}$ ); in other seasons, there was no significant difference (703.1 $\left.\mathrm{g} \mathrm{kg}^{-1}\right)$. cv. Basilisk presented a higher value in spring $\left(740.9 \mathrm{~g} \mathrm{~kg}^{-1}\right)$ and a lower value in summer $\left(665.8 \mathrm{~g} \mathrm{~kg}^{-1}\right)$. These results are satisfactory for the leaves of Urochloa grass.

When comparing the averages of IVDNDF in the same season, it was observed that there was a significant difference $(\mathrm{P}<0.05)$ between cv. Tupi, ecotype R124 and ecotype D70. cv. Tupi showed the lowest average $\left(546.2 \mathrm{~g} \mathrm{~kg}^{-1}\right)$, whereas the D70 showed the greatest IVDNDF in summer $(679.2 \mathrm{~g}$ $\left.\mathrm{kg}^{-1}\right)$, autumn $\left(740.4 \mathrm{~g} \mathrm{~kg}^{-1}\right)$ and winter $\left(711.3 \mathrm{~g} \mathrm{~kg}^{-}\right.$ $\left.{ }^{1}\right)$. In the spring, the highest averages were found for cv. Comum (735.1 $\mathrm{g} \mathrm{kg}^{-1}$ ) and cv. Basilisk (740.9 g $\mathrm{kg}^{-1}$, Table 2). Cv. Comum had the greatest variation across seasons, with a lower value in summer $(526.4$ $\left.\mathrm{g} \mathrm{kg}^{-1}\right)$ and a greater value in spring $\left(678.1 \mathrm{~g} \mathrm{~kg}^{-1}\right)$. The D70 ecotype presented the greatest IVDADF 
across grasses and seasons during autumn $(712.0 \mathrm{~g}$ $\mathrm{kg}^{-1}$; Table 4). The R124 ecotype showed a higher ADF digestibility (840.9 $\mathrm{g} \mathrm{kg}^{-1}$ ) in autumn and the smallest value in summer $\left(729.3 \mathrm{~g} \mathrm{~kg}^{-1}\right)$. The R124 ecotype showed a higher digestibility of grasses across seasons (840.9 $\left.\mathrm{g} \mathrm{kg}^{-1}\right)$.

The coefficients of the determination $\left(\mathrm{R}^{2}\right)$ obtained in gas-production analysis were greater than $89 \%$, showing a good fit of the bicompartmental logistic model for describing the kinetics of ruminal fermentation in this study (Table 3). It was observed in spring a high protodioscin content in the composition of grasses and smaller values of fraction A (soluble sugars and starch) that are readily fermentable carbohydrates, except for the R124 ecotype. Possibly due to the anti-nutritional factor, protodioscin interferes with the harnessing dynamic of this fraction.

Comparing the grasses studied, the R124 ecotype obtained the largest average total cumulative production of gases across seasons (an average of $12.38 \mathrm{ml}$ gas $100 \mathrm{mg} \mathrm{DM}^{-1}$ ), with $10.89 \mathrm{~mL}$ gas at $100 \mathrm{mg} \mathrm{DM}^{-1}$ in fraction $\mathrm{D}$, and $1.49 \mathrm{~mL}_{\text {gas }}$ at 100 mg $\mathrm{DM}^{-1}$ in fraction $\mathrm{A}$.

The D70 ecotype showed higher cumulative gas production in the summer, the same period that showed the lowest protodioscin content. It had a high presence of the anti-nutritional factor and a lower total gas production, which was observed for IVDDM. This dynamic is demonstrated by the Pearson correlation (Table 4).

The shorter colonization time of bacteria in the grasses may be related to ruminal liquid characteristics, which strongly influence the gasproduction technique. These fractions contributed to greater gas production in the first 12 hours of incubation and during this period were the main energy source for microbial growth. In tropical grasses, primarily in the advanced stadium of maturity, the NDF fraction contributed the largest proportion of gas produced throughout incubation. The same behavior was observed in the grasses in which fraction D (cellulose and hemicellulose) comprised on average $88.12 \%$ of the total production of gases produced, and fraction A comprised $11.88 \%$.

The average annual contribution of fraction $\mathrm{E}$ demonstrates that grasses with a low concentration of the anti-nutritional compound showed low degradation rates of slowly digesting fractions $\left(\mathrm{g} \mathrm{kg}^{-1} \mathrm{~h}\right)$, whereas the with high concentrations showed higher degradation times.

There was a highly significant negative correlation $(-0.64)$ between NDF and IVDDM; the high NDF influenced the decline in IVDMD. Contrarily, there was a significant positive correlation between CP and IVDDM $(+0.73)$ and IVDOM $(+0.63)$, which suggests that the presence of $\mathrm{CP}$ positively influences the digestibility of DM and OM without affecting the total cumulative production of gas (Table 4). However, there was a significant negative correlation $(-0.22)$ between the protodioscin content and the lag time (fraction $\mathrm{C}$ ) and between the protodioscin content and total gas production $(-0.25)$. Low interference likely occurred in the dynamics of the fermentation of rapid fractions, the average interference in the bacterial colonization of time and the degradation of the slow fraction due to concentration of protodioscin present in the rumen fluid. 
Table 3. Cumulative gas production parameters of Urochloa grasses.

\begin{tabular}{|c|c|c|c|c|c|c|}
\hline \multirow{2}{*}{ Parameters } & \multicolumn{2}{|c|}{ U. humidicola } & \multicolumn{2}{|c|}{ U. decumbens } & \multirow{2}{*}{$\begin{array}{c}\text { U. ruziziensis } \\
\text { R124 }\end{array}$} & \multirow{2}{*}{$\mathrm{P}$} \\
\hline & Comum & Tupi & Basilisk & D70 & & \\
\hline \multicolumn{7}{|c|}{ Summer } \\
\hline $\mathrm{A}(\mathrm{mL})$ & $1.81 \mathrm{a}$ & $1.33 \mathrm{~b}$ & $1.84 \mathrm{a}$ & $1.29 \mathrm{~b}$ & $1.93 \mathrm{a}$ & 0.001 \\
\hline $\mathrm{B}\left(\mathrm{g} \mathrm{kg}^{-1} \cdot \mathrm{h}\right)$ & $8.9 \mathrm{~b}$ & $9.1 \mathrm{ab}$ & $8.9 \mathrm{~b}$ & $8.9 \mathrm{~b}$ & $9.2 \mathrm{a}$ & 0.001 \\
\hline $\mathrm{C}(\mathrm{h})$ & $9.96 \mathrm{a}$ & $6.87 \mathrm{bc}$ & $6.35 \mathrm{bc}$ & $7.95 \mathrm{~b}$ & $5.71 \mathrm{c}$ & 0.001 \\
\hline $\mathrm{D}(\mathrm{mL})$ & $8.51 \mathrm{a}$ & $9.40 \mathrm{a}$ & $6.37 \mathrm{~b}$ & $9.26 \mathrm{a}$ & $8.85 \mathrm{a}$ & 0.001 \\
\hline $\mathrm{E}\left(\mathrm{g} \mathrm{kg}^{-1} \cdot \mathrm{h}\right)$ & $0.28 \mathrm{a}$ & $0.36 \mathrm{a}$ & $0.26 \mathrm{a}$ & $0.40 \mathrm{a}$ & $0.38 \mathrm{a}$ & 0.154 \\
\hline Total (mL) & $10.33 \mathrm{ab}$ & $10.73 \mathrm{a}$ & $8.21 \mathrm{~b}$ & $10.55 \mathrm{a}$ & $10.78 \mathrm{a}$ & 0.001 \\
\hline $\mathrm{R}^{2}$ & 0.97 & 0.97 & 0.94 & 0.99 & 0.89 & \\
\hline \multicolumn{7}{|c|}{ Autumn } \\
\hline $\mathrm{A}(\mathrm{mL})$ & $1.99 \mathrm{a}$ & $1.28 \mathrm{~b}$ & $1.89 \mathrm{a}$ & $1.15 \mathrm{~b}$ & $1.26 \mathrm{~b}$ & 0.001 \\
\hline $\mathrm{B}\left(\mathrm{g} \mathrm{kg}^{-1} \cdot \mathrm{h}\right)$ & $9.4 \mathrm{a}$ & $8.9 \mathrm{~b}$ & $9.4 \mathrm{a}$ & $8.9 \mathrm{~b}$ & $9.0 \mathrm{~b}$ & 0.001 \\
\hline $\mathrm{C}(\mathrm{h})$ & $3.00 \mathrm{c}$ & $7.24 \mathrm{a}$ & $5.33 \mathrm{~b}$ & $6.47 \mathrm{ab}$ & $4.96 \mathrm{~b}$ & 0.001 \\
\hline $\mathrm{D}(\mathrm{mL})$ & $10.16 \mathrm{ab}$ & $10.61 \mathrm{a}$ & $9.53 \mathrm{c}$ & $8.10 \mathrm{~d}$ & $9.99 b c$ & 0.001 \\
\hline $\mathrm{E}\left(\mathrm{g} \mathrm{kg}^{-1} \cdot \mathrm{h}\right)$ & $0.39 \mathrm{c}$ & $0.27 \mathrm{~d}$ & $0.44 \mathrm{~b}$ & $0.51 \mathrm{ab}$ & $0.55 \mathrm{a}$ & 0.001 \\
\hline Total (mL) & $12.15 \mathrm{a}$ & $11.89 \mathrm{ab}$ & $11.42 \mathrm{ab}$ & $9.25 \mathrm{c}$ & $11.25 \mathrm{~b}$ & 0.001 \\
\hline $\mathrm{R}^{2}$ & 0.93 & 0.99 & 0.98 & 0.96 & 0.97 & \\
\hline \multicolumn{7}{|c|}{ Winter } \\
\hline $\mathrm{A}(\mathrm{mL})$ & $0.57 \mathrm{c}$ & $0.67 b c$ & $1.07 \mathrm{ab}$ & $0.30 \mathrm{c}$ & $1.31 \mathrm{a}$ & 0.001 \\
\hline $\mathrm{B}\left(\mathrm{g} \mathrm{kg}^{-1} \cdot \mathrm{h}\right)$ & $9.6 \mathrm{~b}$ & $8.9 \mathrm{~d}$ & $9.9 \mathrm{a}$ & $9.2 \mathrm{c}$ & $9.1 \mathrm{~cd}$ & 0.001 \\
\hline $\mathrm{C}(\mathrm{h})$ & $4.91 \mathrm{~b}$ & $8.87 \mathrm{a}$ & $5.96 \mathrm{~b}$ & $5.25 \mathrm{~b}$ & $6.36 \mathrm{~b}$ & 0.001 \\
\hline $\mathrm{D}(\mathrm{mL})$ & $6.66 \mathrm{c}$ & $10.02 \mathrm{a}$ & $6.76 \mathrm{c}$ & $8.57 \mathrm{~b}$ & $9.72 \mathrm{a}$ & 0.001 \\
\hline $\mathrm{E}\left(\mathrm{g} \mathrm{kg}^{-1} \cdot \mathrm{h}\right)$ & $0.52 \mathrm{a}$ & $0.43 \mathrm{a}$ & $0.43 \mathrm{a}$ & $0.38 \mathrm{a}$ & $0.48 \mathrm{a}$ & 0.151 \\
\hline Total (mL) & $7.23 \mathrm{c}$ & $10.69 \mathrm{a}$ & $7.83 \mathrm{c}$ & $8.87 \mathrm{~b}$ & $11.04 \mathrm{a}$ & 0.001 \\
\hline $\mathrm{R}^{2}$ & 0.96 & 0.99 & 0.88 & 0.99 & 0.98 & \\
\hline \multicolumn{7}{|c|}{ Spring } \\
\hline $\mathrm{A}(\mathrm{mL})$ & $0.37 \mathrm{c}$ & $0.41 \mathrm{c}$ & $1.24 \mathrm{a}$ & $0.81 \mathrm{~b}$ & $1.46 \mathrm{a}$ & 0.001 \\
\hline $\mathrm{B}\left(\mathrm{g} \mathrm{kg}^{-1} \cdot \mathrm{h}\right)$ & $8.9 \mathrm{~d}$ & $9.9 \mathrm{a}$ & $9.1 \mathrm{c}$ & $9.7 \mathrm{~b}$ & $8.9 \mathrm{~d}$ & 0.001 \\
\hline $\mathrm{C}(\mathrm{h})$ & $11.99 \mathrm{a}$ & $3.01 \mathrm{e}$ & $4.00 \mathrm{~d}$ & $5.35 \mathrm{c}$ & $7.04 \mathrm{~b}$ & 0.001 \\
\hline $\mathrm{D}(\mathrm{mL})$ & $9.50 \mathrm{~b}$ & $6.92 \mathrm{c}$ & $8.96 \mathrm{~b}$ & $5.18 \mathrm{~d}$ & $14.98 \mathrm{a}$ & 0.001 \\
\hline $\mathrm{E}\left(\mathrm{g} \mathrm{kg}^{-1} \cdot \mathrm{h}\right)$ & $0.14 \mathrm{~d}$ & $0.39 \mathrm{c}$ & $0.55 \mathrm{~b}$ & $0.69 \mathrm{a}$ & $0.52 \mathrm{~b}$ & 0.001 \\
\hline Total (mL) & $9.87 \mathrm{~b}$ & $7.32 \mathrm{c}$ & $10.19 \mathrm{~b}$ & $5.99 \mathrm{~d}$ & $16.44 \mathrm{a}$ & 0.001 \\
\hline $\mathrm{R}^{2}$ & 0.99 & 0.94 & 0.97 & 0.99 & 0.98 & \\
\hline
\end{tabular}

* Means followed by distinct letters, lowercase in the column and uppercase on the line, differ by Tukey test $(\mathrm{P}<0.05)$. A and $\mathrm{D}$ are the volume of gas from the rapid digestion (soluble sugars and amido) and slow digestion (cellulose and hemicellulose), respectively; $\mathrm{B}$ and $\mathrm{E}$ correspond to the degradation rate of the fast and slow degradation portions, respectively; $\mathrm{C}$ is the time lag, bacterial colonization of time; Total is the sum of the fraction A + D; R2 is the coefficient of determination.

Table 4. Pearson correlations between nutrition, digestibility and cumulative gas production.

\begin{tabular}{lccccccc}
\hline & PROTO & CP & NDF & IVDMD & IVDOM & C & Gas Total \\
\cline { 2 - 7 } PROTO & 1.00 & $0.27^{*}$ & $-0.17^{*}$ & $0.53^{*}$ & $0.17^{*}$ & $-0.22^{*}$ & $-0.25^{*}$ \\
CP & $0.27^{*}$ & 1.00 & $-0.64^{*}$ & $0.73^{*}$ & $0.63^{*}$ & -0.03 & $-0.09^{*}$ \\
NDF & $-0.17^{*}$ & $-0.64^{*}$ & 1.00 & $-0.64^{*}$ & $-0.46^{*}$ & -0.05 & $0.08^{*}$ \\
IVDMD & $0.53^{*}$ & $0.73^{*}$ & $-0.64^{*}$ & 1.00 & $0.65^{*}$ & -0.01 & $-0.23^{*}$ \\
IVDOM & $0.17^{*}$ & $0.63^{*}$ & $-0.46^{*}$ & $0.65^{*}$ & 1.00 & $-0.06^{*}$ & -0.03 \\
C & $-0.22^{*}$ & -0.03 & -0.05 & -0.01 & $-0.06^{*}$ & 1.00 & $0.22^{*}$ \\
Gas Total & $-0.25^{*}$ & $-0.09^{*}$ & $0.08^{*}$ & $-0.23^{*}$ & -0.03 & $0.22^{*}$ & 1.00 \\
\hline
\end{tabular}

* $\mathrm{P}<0.05$; $\mathrm{PROTO}=$ protodioscin; $\mathrm{CP}=$ crude protein; $\mathrm{NDF}=$ neutral detergent fiber; IVDDM= digestibility in vitro dry matter; $\mathrm{IVDOM}=$ in vitro digestibility of organic matter; $\mathrm{C}=$ lag time $(\mathrm{h})$; Total $=\mathrm{A}+\mathrm{D}$. 
In the tropical grasses, particularly in the advanced stage of maturity, the NDF fraction contributed the largest proportion of gas produced during incubation (CABRAL et al., 2000), confirming the findings obtained in this work. Similarly, Cone and Van Gelder (1999) observed that the incubation of young forage and a high CP content generated an inexplicably lower production of gas than older plants with a lower $\mathrm{CP}$ content. Each percentage unit of protein fermented reduced the $2.48 \mathrm{ml}$ of gas to $100 \mathrm{mg}$ of $\mathrm{MO}^{-1}$, particularly in the early hours of incubation, due to the fermentation of soluble proteins, which could affect the final volume of gas of non-fiber carbohydrates.

\section{Conclusion}

Urochloa decumbens cv. Basilisk and the Urochloa decumbens D70 ecotype show high levels of saponin protodioscin. The D70 features high quality, as assessed by the digestibility and kinetics of degradation in the rumen liquid in vitro. The Urochloa ruziziensis R124 ecotype features high cumulative gas production in all seasons. The protodioscin content influences digestibility results and cumulative gas production in vitro.

\section{References}

BARBOSA, J. D.; OLIVEIRA, C. M. C.; TOKARNIA, C. H.; PEIXOTO, C. V. Fotossensibilização hepatógena em equinos pela ingestão de Brachiaria humidicola (Gramineae) no estado do Pará. Pesquisa Veterinária Brasileira, Seropédica, v. 26, n. 3, p. 147-153, 2006.

BERCHIELLI, T. T.; SADER, A. P. O.; TONANI, F. L.; PAZIANI, S. F.; ANDRADE, P. Avaliação da determinação da fibra em detergente neutro e da fibra em detergente ácido pelo sistema ANKOM. Revista Brasileira de Zootecnia, Viçosa, MG, v. 30, n. 5, p. 15721578, 2001.

BRUM, K. B.; HARAGUCHI, M.; GARUTTI, M. B.; NÓBREGA, F. N.; ROSA, B.; FIORAVANTI, M. C. S. Steroidal saponin concentrations in Brachiaria decumbens and Brachiaria brizantha at different developmental stages. Ciência Rural, Santa Maria, v. 39, n. 1, p. 279-281, 2009.
BRUM, K. B.; HARAGUCHI, M.; LEMOS, R. A. A.; FIORAVANTI,M.C.S.Crystal-associatedcholangiopathy in sheep grazing Brachiraria decumbens containing thesaponinprotodioscin. Pesquisa Veterinária Brasileira, Seropédica, v. 27, n. 1, p. 39-42, 2007.

CABRAL, L. S.; VALADARES FILHO, S. C.; MALAFAIA, P. A. M.; LANA, R. P.; SILVA, J. F. C.; VIEIRA, R. A. M.; PEREIRA, E. S. Frações de Carboidratos de alimentos volumosos e suas taxas de degradação estimadas pela técnica de produção de gases. Revista Brasileira de Zootecnia, Viçosa, MG, v. 29, n. 6, p. 2087-2098, 2000.

CANNAS, A.; TEDESCHI, L. O.; FOX, D. G.; PELL, A. N.; VAN SOEST, P. J. A mechanistic model for predicting the nutrient requirements and feed biological values for sheep. Journal of Animal Science, Champaign, v. 82, n. 1, p. 149-169, 2004.

CARVALHO, D. M. G.; CABRAL, L. S.; SILVA, J. J.; ABREU, J. G.; GALATY, R. L.; GENTILE, G. G. P.; CAMARGO, L. M.; SOARES, J. Q.; RUFINO JUNIOR, J. Suplementos para terminação de ovinos em pastos de Brachiaria brizantha cv. Marandu. Semina: Ciências Agrárias, Londrina, v. 36, n. 1, p. 313-326, 2015.

CONE, J. W.; VAN GELDER, A. H. Influence of protein fermentation on gas production profiles. Animal Feed Science Technology, Amsterdam, v. 76, n. 3-4, p. 251264, 1999.

CRUZ, C.; DRIEMEIER, D.; PIRES, V. S.; COLODEL, E. M.; TAKETA, A. T. C.; SCHENKEL, E. P. Isolation of steroidal sapogenins implicated in experimentally induced cholangiopathy of sheep grazing Brachiariadecumbens in Brazil. Veterinary and HumanToxicology, Manhattan, v. 42, n. 3, p. 142-145, 2000.

DRIEMEIER, D.; BARROS, S. S.; PEIXOTO, P. V.; TOKARNIA, C. H.; BRITO, M. F. Estudos histológico e ultra-estrututral de fígados e linfonodos de bovinos com presença de macrófagos espumosos ("foam cells"). Pesquisa Veterinária Brasileira, Seropédica, v. 18, n. 1, p. 29-34, 1998.

EL-WAZIRY, A. M.; NASSER, M. E. A.; SALLAM, S. M. A.; ABDALLAH, A. L.; BUENO, I. C. S. Processing methods of soybean meal. effect of autoclaving and quebracho tannin treated-soybean meal on gas production and rumen fermentation in vitro. Journal of Applied Sciences Research, Amman, v. 3, n. 1, p. 17-24, 2007.

FIORENTIN, C. F.; LEMOS, L. B.; FORNASIERI FILHO, D.; JARDIM, C. A. Influência da consorciação com Brachiaria ruzisiensis e do nitrogênio residual na cultura do milho. Revista de Ciências Agrárias, Lisboa, v. 35, n. 1, p. 184-192, 2012. 
FOX, D. G.; TEDESCHI, L. O.; TYLUTKI, T. P.; RUSSEL, J. B.; Van HANBURGH, M. E.; CHASE, L. E.; PELL, A. N.; OVERTON, T. R. The cornell net carbohydrate and protein system model for evaluating herd nutrition and nutrient excretion. Animal Feed Science Technology, Amsterdam, v. 112, n. 1-4, p. 29-78, 2004.

GANZERA, M.; BEDIR, E.; KHAN, I. A. Determination of steroidal saponins in Tribulusterrestris by reversedphase high-performance liquid chromatography and evaporative light scattering detection. Journal Pharmaceutical Sciences, Hoboken, v. 90, n. 11, p. 17521758, 2001.

HOLDEN, L. A. Comparison of methods of in vitro matter digestibility for ten feeds. Journal of Dairy Science, Madison, v. 2, n. 8, p. 1791-1794, 1999.

KOZLOSKI, G. V.; TREVISAN, L. M.; BONNECARRERÉ, L. M.; HÄRTER, C. J.; FIORENTINI, G.; GALVANI, D. B.; PIRES, C. C. Níveis de fibra em detergente neutro na dieta dos cordeiros: consumo, digestibilidade e fermentação ruminal. Arquivo Brasileiro de Medicina Veterinária e Zootecnia, Belo Horizonte, v. 58, n. 5, p. 893-900, 2006.

LEMOS, R. A. A.; NAKAZATO, L.; HERRERO JÚNIOR, G. O.; SILVEIRA, A. C.; PORFIRIO, L. C. Fotossensibilização e colangiopatia associada a cristais em caprinos mantidos sob pastagens de Brachiaria decumbens no Mato Grosso do Sul. Ciência Rural, Santa Maria, v. 28, n. 3, p. 507-510, 1998.

MENDONÇA, F. S.; CAMARGO, L. M.; FREITAS, S. H.; DÓRIA, R. G. S.; BARATELLA-EVÊNCIO, L. NETO, J. E. Aspectos clínicos e patológicos de um surto de fotossensibilização hepatógena em ovinos pela ingestão de Brachiaria decumbens (Gramineae) no município de Cuiabá, Mato Grosso. Ciência Animal Brasileira, Goiânia, v. 9, n. 4, p. 1034-1041, 2008.

MORAES, E. H. B. K.; PAULINO, M. F.; ZERVOUDAKIS, J. T.; VALADARES FILHO, S. C.; MORAES, K. K. Avaliação qualitativa da pastagem diferida de Brachiaria decumbens Stapf., sob pastejo, no período da seca, por intermédio de três métodos de amostragem. Revista Brasileira de Zootecnia, Viçosa, MG, v. 34, n. 1, p. 30-35, 2005.

MOREIRA, L. M.; MARTUSCELLO, J. A.; FONSECA, D. M.; MISTURA, C.; MORAIS, R. V. E.; RIBEIRO JÚNIOR, J. I. Perfilhamento, acúmulo de forragem e composição bromatológica do capim-braquiária adubado com nitrogênio. Revista Brasileira de Zootecnia, Viçosa, MG, v. 38, n. 9, p. 1675-1684, 2009.
PELL, A. N.; SCHOFIELD, P. Computerized monitoring of gas production to measure forage digestion in vitro. Journal of Dairy Science, Madison, v. 76, n. 4, p. 10631073, 1993.

PORTO, M. R.; SATURNINO, K. C.; LIMA, E. M. M.; LEE, S. T.; LEMOS, R. A. A.; MARCOLONGOPEREIRA, C.; RIET-CORREA, F.; CASTRO, M. B. Avaliação da exposição solar na intoxicação experimental por Brachiaria decumbens em ovinos. Pesquisa Veterinária Brasileira, Seropédica, v. 33, n. 8, p. 10091015, 2013.

RIET-CORREA, B.; CASTRO, M. B.; LEMOS, R. A. A.; RIET-CORREA, G.; MUSTAFA, V.; RIET-CORREA, F. Brachiaria spp. poisoning of ruminants in Brazil. Pesquisa Veterinária Brasileira, Seropédica, v. 31, n. 3, p. 183-192, 2011.

SANTOS, J. C. A.; RIET-CORREA, F.; SIMÕES, S. V. D.; BARROS, C. S. L. Patogênese, sinais clínicos e patologia das doenças causadas por plantas hepatotóxicas em ruminantes e equinos no Brasil. Pesquisa Veterinária Brasileira, Seropédica, v. 28, n. 1, p. 1-14, 2008.

SATURNINO, K. C.; MARIANI, T. M.; FERREIRA, M. B.; BRUM, K. B.; FERNANDES, C. E. S.; LEMOS, R. A. A. Intoxicação experimental por Brachiaria decumbens em ovinos confinados. Pesquisa Veterinária Brasileira, Seropédica, v. 30, n. 3, p. 195-202, 2010.

SILVA, D. J.; QUEIROZ, A. C. Análise de alimentos métodos químicos e biológicos. Viçosa, MG: UFV, 2002. $235 \mathrm{p}$.

SILVA, M. C.; SANTOS, M. V. F.; DUBEUX JÚNIOR, J. C. B.; LIRA, M. A.; MELO, W. S.; OLIVEIRA, T. N.; ARAÚJO, G. G. L. Avaliação de métodos para recuperação de pastagens de braquiária no Agreste de Pernambuco. 2. Valor nutritivo da forragem. Revista Brasileira de Zootecnia, Viçosa, MG, v. 33, n. 6, p. 2007 2016, 2004.

TILLEY, J. M. A.; TERRY, R. A. A two stage technique for the in vitro digestion of forage crops. Journal of the British Grassland Society, Oxford, v. 18, n. 2, p. 104-111, 1963.

UNIVERSIDADE FEDERAL DE VIÇOSA - UFV. Central de processamento de dados - UFV/CPD. Manual de utilização do Programa SAEG - Sistema para análises estatísticas e genéticas. Viçosa, MG: UFV, 1997. 59 p.

VAN SOEST, P. J. Nutritional ecology of the ruminant. $2^{\text {th }}$ ed. Ithaca: Cornell University Press, 1994. 476 p.

Voluntary intake relation to chemical composition and digestibility. Journal of Animal Science, Champaign, v. 24, n. 3, p. 834-844, 1965. 
